Вісник Львівського університету. Серія філос.-політолог. студіі. 2020. Випуск 29, с. 61-68

Visnuk of the Lviv University. Series Philos.-Political Studies. Issue 29, p. 61-68

UDC 1.27-31

DOI https://doi.org/10.30970/PPS.2020.29.8

\title{
AUTOCEPHALIC PRINCIPLE OF THE CHURCH-ADMINISTRATIVE STRUCTURE OF THE EARLY CHRISTIAN PERIOD
}

\author{
Andriy Kobetyak \\ Zhytomyr Ivan Franko State University, \\ Department of Philosophy and Political Science \\ Velyka Berdychivska str., 40, 10008, Zhytomyr, Ukraine
}

The basic principles and mechanisms of functioning of the church-administrative system of management in the early Christian period are considered. Since Orthodoxy has positioned as an extremely conservative religion, it is necessary to study in detail the "ideal" period of the spread of the Christian faith and the formation of the first communities. The modern system of the Ecumenical Church has significant differences. Gradually, two opposing ecclesiological traditions (Greek and Slavic) emerged, indicating a lack of Unity and Conciliarity. The formation of two approaches to understanding the structure of the system of universal Orthodoxy was the reason for calling the Great All-Orthodox Council in 2016.

It has proved that the apostles and their closest disciples did not know and did not foresee any other principle of the existence of the Ecumenical Church than autocephaly. Each of the established communities was a priori independent. The apostles and their successors, the bishops, played a preaching and liturgical role. There is no written mention of any external management of the church. Autocephaly and catholicity are positioning as basic categories of church institutionalization. Autocephaly is one of the oldest institutions of the Church, which is a defining feature of Orthodoxy today. Although the very phenomenon of autocephaly remains unchanged, during the long history of Orthodoxy, different approaches to its understanding have formed. From the state of nature, in the pre-Nicene period, autocephaly has transformed into a privileged state, which has endowed with five ancient patriarchates, as evidenced by the canons and rules of the Ecumenical Councils. It is important that the Councils did not work out a mechanism for further granting autocephalous status to the newly formed churches. The theory of "pentarchy" did not provide for the possibility of autocephaly of new churches.

The example of resolving church disputes and combating the first heresies in the early Christian period should use by modern hierarchs. Today the Ecumenical Church is on the verge of a great schism. Several local churches broke off the Eucharistic communion, which symbolizes common unity. The ideals of early Christianity are lost. Therefore, further detailed research of the pre-Nicene period and the institutionalization of the autocephalous church system of that time will serve to establish a tolerant dialogue between the hierarchs of the Local Churches in the XXI century.

Key words: Christianity, cathedral, Orthodox Church, Tomos, diptych, Ecumenical patriarch, autocephaly, canon.

The signing of the Tomos for the Orthodox Church of Ukraine and the related church and political events once again drew attention to the autocephalous issue. The Ecumenical Church has repeatedly tried to solve the problem of granting autocephalous status to the people of a particular country. Whenever the question of the independence of the new church was raised, leading theologians and hierarchs paid attention to this question. Today there is no single document that regulate the process of signing the Tomos and granting autocephaly status. Thus, autocephaly periodically granted to various churches, the last of which for the Ukrainian Church in 2019, but a generally accepted mechanism with a clear algorithm of action was not adopt. Moreover, the document "Autocephaly and ways to proclaim it", which was to be signed in 2016, was one

(C) A. Kobetyak, 2020 
of the main reasons for the failure of the Great All-Orthodox Council in Crete. Thus, the world scientific and religious community has once again intensified the study of the autocephalous principle of the existence of the Universal Orthodoxy, in connection with the discussion of the Local Churches on the recognition of the newly proclaimed PCU. It is important to study the early Christian period, in which the main principles and mechanisms of the Church's existence in general formed.

Leading theologians, hierarchs and great fathers of the Church addressed the issue of autocephaly and the structure of the Ecumenical Church. There were certain "bursts" of theological thought, as in the era of the Ecumenical Councils and periods of decline. Today, scholars, hierarchs and theologians are once again actively discussing the church situation, which connected with the crisis of Orthodoxy in general and the intensification of the Orthodox-Catholic dialogue. The Great Cretan Council of 2016 and the granting of the Tomos to the Ukrainian Church were especially noteworthy.

The state of scientific development of the chosen topic today is ambiguous. On the one hand, there are hundreds of public statements, speeches and official letters from hierarchs and theologians from various Local Churches regarding autocephaly. Most of them are polemical. On the other hand, the scientific substantiation of autocephaly topics has significantly intensified. Especially valuable are the works of researchers of Ukrainian church history and the canonical structure of the Orthodox Church I. Vlasovsky, O. Kyridon, O. Lototsky, Y. Mulyk-Lutsyk and others, who repeatedly drew attention to the period of early Christianity and the emergence of the institution of autocephaly.

Among the scholars who studied the early period of Christianity, it is necessary to single out world-renowned researchers of church history: V. Asmus, A. von Harnack, J. Robertson, A. Kartashev, E. Caesariysky, N. Milash, E. Smirnov, S. Smirnov, K. Skurat, F. Uspensky and many others. The works of the mentioned authors reveal the main periods of development and the objective-situational conditionality of the autocephalous principle of the church's existence.

It is necessary to mention separately the modern dissertation researches of V. Butynsky, M. Gergelyuk who reveal the process of autocephalous formation of Orthodox churches. In modern researches of domestic scientists, the deep analysis of autocephalous problems in the key of the Ukrainian question is trace. The work of the famous national theologian Archimandrite Kirill (Govorun) is important. In particular, his dissertation on ecclesiology is relevant, in which much attention has paid to the early Christian period and the problem of autocephaly. Fundamental is V. Bolotov's four-volume book on the history of the ancient Church, in which the external ecclesiastical growth of the parish network and the internal system of early Orthodox Orthodoxy are gradually reveal. In general, the works of leading researchers A. Aristova, D. Gorevy, O. Gorkusha, V. Yelensky, S. Zdioruk, A. Kolodny, P. Kraliuk, O. Sagan, P. Saukh, A. Smirnova, L. Filipovich, Y. Chornomorets, A. Yurash and others are devoted to the religious and philosophical understanding of the processes of autocephaly in Orthodox canonism.

Despite considerable scientific and secular interest in the topic of research, today there are a number of unresolved issues regarding the autocephalous system and canon law of the early period of Christianity. In addition, the very autocephalous principle of the existence of the Ecumenical Church in the period before the Ecumenical Councils has not clarified. The presence of a number of unresolved scientific problems concerning the autocephalous structure of the Ecumenical Church in the early Christian period significantly actualizes the chosen topic.

The aim of the article is to study the autocephalous principle of the church-administrative system in the period of early Christianity. It is necessary to establish non/conformity 
with the mechanisms of governing the church structure laid down by the apostles, the modern arrangement of the Ecumenical Church. The main question is whether the principles and ideals of the early Christian church correspond to the current division of the United Church into Local Autocephalous Organizations.

Orthodoxy has always positioned itself as a conservative system of doctrine that has made minimal changes in its two-thousand-year history. Thus, there is a constant motive for a return to the early Christian ideals of life and church organization. On the other hand, over the years 2000, Christianity has acquired significant layers. Dogmas, canons of the church and the basic principles of its administrative existence were form. There is no doubt, that during existence, religion, including Orthodoxy, has significantly politicized and to some extent became dependent on state power. An example is the proclamation of new autocephaly in the Balkans, when due to pressure from governments in the international arena of the newly proclaimed countries signed the Tomos for their churches (Hellenic, Polish, and Bulgarian HRC) [1, p. 104]. Therefore, the study of the early Christian "ideal" period and the autocephalous structure of the churches in the first centuries of our era is significantly relevant.

Due to the events surrounding the signing of the Tomos for the PCU, fundamental differences in the ecclesiology of the Local Churches became apparent. Most ordinary citizens, and sometimes scholars, consider Orthodoxy to be a monolithic entity. The doctrine for all Orthodox world is unique, but functional, for ease of management and coordination, the Ecumenical Church has divided into separate Local Entities, which are independent. Thus, the national interest of religious citizens could take into account. Thus, the idea has formed that the general doctrine has unified, and the Local Churches form a single whole of one common church. Indeed, this is a conditional ideal of the life of the Orthodox Church, which has laid down from the first centuries, but today there are significant differences in theological teaching, especially ecclesiology (the science of church structure). As a result, the theological debate and the loss of church unity in 2020, which manifested itself in the rupture of the Eucharistic communion as a symbol of the homogeneity of the Church. Ecumenical Orthodoxy is on the verge of a great schism, which significantly actualizes the study of the period of early Christianity as an "ideal" stage of the church's existence. Differences in the teachings of the Local Churches also affected the fundamental doctrine of church structure. For some of the Local Churches (of Greek origin, which focus on Constantinople), there is a "gathering point" in the Ecumenical Church. It was once the Roman chair, as the first among equals and the capital of the empire. After the division in 1054, the prerogatives of the primacy took over the throne of Constantinople. The "collection point" has special rights and responsibilities, and this is primarily due to the right of the arbitral tribunal of the highest instance and the gift of autocephaly.

To confirm this, in 1950 the Patriarch of Constantinople Athenagoras published a district message stating that the Local Churches "communicate" only through the Ecumenical Patriarchate. This is the only way they have a connection with each other. The rupture for any reason with Constantinople means a rupture with Orthodoxy in general [2, p. 213]. This document certifies the official ecclesiological position of the structure of world Orthodoxy Fanar. From it follows the model of the relationship of Constantinople with the Local Churches. Although officially the Local Churches are completely independent and self-governing, the Ecumenical Hierarch can act as the supreme arbiter and overseer of the observance of canonical precepts. This is made possible through the exercise of the right of appeal to him by hierarchs from around the world, as well as through the leadership and feeding of the diaspora of other churches.

For the rest of the churches (mostly Slavic, Moscow-oriented) there can be no single point of contact. Each of the Local Churches is completely independent, in no way accountable to any- 
one and has the right to grant autocephaly to its autonomous part (daughter Church). The Local Church has subordinated only to the Ecumenical Council [3, p. 93]. The second point of view is much newer in time, because the Slavic churches appeared after the era of the Ecumenical Councils, so this position has not reflected in the canons of the church. Instead, some Local Churches, such as the ROC, adopted a document in 2013 on the primacy of the Orthodox world [4]. The decision of the Holy Synod denies the salty status of the Constantinople chair as having administrative advantages over other Local Churches. The system of local churches has presented in the form of a confederation of equal sister churches. At that time, the Constantinople chair has endowed exclusively with the spiritual advantages of honor during worship and ceremonies.

Orthodox ecclesiology has based on the canons and rules of the church, which have created in specific historical conditions, as a reaction to a certain problem, such as heresy. In addition, the church lived within a great empire and an absolute monarchy. Therefore, the first version of the prerogative of the Constantinople department is a variant of literal observance of canons and rules, which to some extent have lost relevance. The second is more modern and corresponds to the democratic realities and the principle of church catholicity [5, p. 18].

For objectively understand the problem of the autocephalous structure of the Ecumenical Church, it is necessary to consider the period of formation of Christianity as a world religion and the related principle of church government in the first centuries. It is important to understand the terminology, which has transformed largely in 2000 .

In the Slavic tradition, the etymology of the word "church" changed from Gothic. It denotes the church as a building, or rather the premises of the cathedral. In Greek, its equivalent is the word $\beta \alpha \sigma \iota \lambda \iota \kappa \eta$ "Royal house", and in Latin - basilica. This term conveys the "external" sign and refers to the church as a building, in the modern sense - the temple [6, p. 10]. Other European

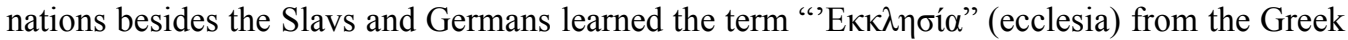
folk assembly. It is in this interpretation that it is appropriate to use the concept of church in the understanding of church organization. In this case, the concept of the church means a specific parish (ecclesia), which from the point of view of canon law is already self-sufficient, especially if it has headed by a bishop. On the other hand, the church (ecclesia) is a large administrative unit of the general system. For example, Ecumenical Orthodoxy is divide into Local Churches, recognized and unrecognized.

It is important to draw a parallel, or rather a line of inheritance from the ancient Jewish (Aramaic) Ed (Edta), which meant the gathering of the Jewish people near the city walls. Each of the members of the Ed was considered equal, and participation in such a meeting was voluntary

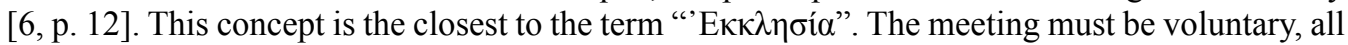
its members are equal, and the notion of Ed and the notion of Ecclesiastical imply that the place and time of the meeting must indicated. As for the text of the Gospel and the words of Christ, the concept of church has used in the text three times, for example, "I will create my church..." (Matthew16:18). Most likely, Christ spoke in Aramaic (Syrian). Accordingly, He used the term "Ed" in these words. The problem is that all three mentions of the church are find in the Gospel of Matthew, which was originally written in Aramaic, and survived only in Greek translations;

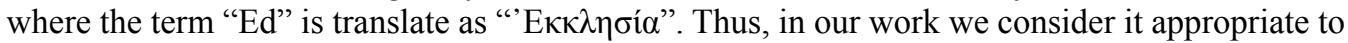
use the term church in the sense of "'Екк $\lambda \eta \sigma i \alpha$ ", which is the maximum equivalent of the Hebrew term "Ed". Thus, the church (ecclesia) is a visible voluntary meeting of believers, which is organize in a separate parish, which in fact is a completely autonomous entity. He who is not a participant in the Ed-ecclesia is not an Israeli, in our case a parishioner of a certain parish [6, p. 13].

The establishment and management of the first communities was natural. Then, at Pentecost, when the Holy Spirit descends on the apostles (Acts 2: 2-4), they spread across the vast 
Roman Empire to preach to all nations. Those who believed have baptized. Obviously, the sermon began in the largest cities in each province. Thus were formed the first communities (Rome, Jerusalem, Ephesus, Corinth, Thessalonica). Due to the persecution of Christians by the Jews, the latter were scattered throughout the Greco-Roman Empire and formed new communities, because they were the authentic bearers of the new religion [7, p. 41]. An important point of the first sermon of Christianity was the sacrificial service of the apostles and their helpers, as well as the example of thousands of martyrs who suffered for the faith. Thus, in a short time an extensive system of parishes was form in various provinces of the empire. A natural question arose about the management of established communities, which were constantly expanding. Church communities needed their own local pastor to perform the rites and strengthen the faith of new converts.

For such needs, the first bishops and elders were ordained, who led the communities founded by the apostles. Later, the first episcopal chairs were form in the largest cities, as there were more crowds of individual parishes. Initially, most honorable bishops were consider to the direct disciples and heirs of the apostles. However, their "advantage" was purely formal and spiritual. However, at the end of the first and the beginning of the second centuries, their influence and power shifted from spiritual superiority to the administrative plane. These were mainly the spiritual leaders of the capitals of entire provinces and major cities. It is obvious that the hierarchs of the capital of the empire stood out. It is to Peter that Christ says that he is the Stone on which the Church is built and which will not be defeated (Matthew 16:18-19). Objectively, grace in the form of the ascension of the Holy Spirit was give equally to all the apostles, but it is Peter and his successors in the Roman See who claim a special status, and later the absolute primacy in Christianity [8, p. 174]. There is no doubt that such an elevation of this throne took place with the support and influence of the capital's authorities. To some extent, the state influences internal church events. By the era of the Ecumenical Councils, the church completely took over the administrative-territorial division according to the state model [7, p. 128]. Other important cities of the empire with adjacent territories formed metropolitanates, which were head by the chief bishop. He could have subordinated several other bishops and elders. By the end of the second century, a prototype of modern Local Autocephalous Churches was formed [3, p. 51]. As the role of individual metropolises and the old and new capitals of the empire increased, five ancient patriarchates were formed (Rome, Constantinople, Alexandria, Antioch, and Jerusalem). Despite certain advantages of honor and claims to the authority of the bishops of Rome, the theory of "pentarchy" - equality and equality of the five independent churches - was form.

The ecclesiology of the early Christian period does not provide for any other ecclesiastical structure of the local church than autocephaly. Each of the independent churches, and ideally since apostolic times all the parishes where the service has held, are already self-sufficient in themselves, are part of the general structure of the Universal Orthodoxy. Autocephaly ensures freedom and, most importantly, equality for Local Churches. This is the basis of the Conciliarity, the basic dogma of the Orthodox faith. Thus, autocephaly is a basic system-forming factor in the internal arrangement of the church structure. The apostolic men simply did not foresee another variant of the church-administrative system. Each parish was already self-sufficient, and the church of a separate province, where the bishop ruled, was the Local Autocephalous Church in the modern sense. It was in the pre-Nicene period that a three-stage institute of the priesthood was formed, the canon of the Holy Scripture was formed and the primary administrative-territorial division according to the state model was recorded [3, p. 50]. The Institute of the Council (Apostolic Council of 1951, a number of Local Councils) appears. Therefore, the study of this period and an example of resolving the church contradictions of the time (the 
celebration of Easter, the baptism of heretics) is an important historical precedent for the pacification of modern church life.

In the first centuries, two different approaches formed in the East and the West to the understanding of ecclesiastical primacy and catholicity, which is directly relate to the autocephalous status of the churches of individual provinces. It is about the role and powers of the Roman chair, as the first among equals. The hierarchs of East and West differently justified the arbitration powers of Rome as the highest instance. Although the canons of the Local Council of Sardis (343) gave the bishops the right to appeal to Rome as a higher authority [9, p. 175].

The autocephalous statuses of the five ancient patriarchates were finally establish in the era of the Ecumenical Councils, which was reflect in specific canons and regulations. In addition, the role of the new capital - Constantinople, as a city where the emperor's residence is located, was especially elevated. During the conciliar period, the church became imperial and largely dependent on state power, which significantly influenced church policy. There were examples when the emperor independently proclaimed the Ecumenical Council and presided over it and made decisions on autocephaly (for example, for the Bulgarians). The choice of candidates for bishops of the capital's departments depended on the state power.

In the context of the formation of ancient patriarchates and metropolitan districts, the first theories of the formation of new independent churches were born. The theory of self-proclamation of autocephaly is important, though contradictory, because then the question arises as to who will be responsible for the observance of the canonical order. It is that autocephaly cannot be granted from outside, because it is already a certain restriction of identity and independence. Once someone created you, and then the Mother Church is responsible for you, which means that the daughter church feels a certain subordination. If at one historical moment, the Matrice Church finds it canonically justified to grant autocephaly, at another it can take it away. At the same time, in the pre-conciliar period the mechanism of interaction between the departments of the capital cities has not been finally form. The autocephalous principle of the church-administrative system was a certain fact of the church arrangement itself. This was self-evident in the first centuries. With the spread of Christianity and the granting of state status, new ecclesiastical districts were form, which sought to acquire autocephalous status, but did not have a direct apostolic origin.

Another important problem is how to resolve the issue of canonical territory, if today it belonged to one church and tomorrow to another. The theory of self-proclamation does not answer a number of questions, in particular where there is a clear line between spontaneity and a mature decision on church independence, whether the newly proclaimed church community fulfills canonical precepts, whether it affects the interests of sister churches and the boundaries of their canonical territory [2, p. 216]. In addition, Rule 2 of the Second Ecumenical Council and Rule 8 of the Third Ecumenical Councils state that the spiritual authority of the first hierarch cannot be mix in territorial terms. Moreover, by declaring ourselves independent, we take away territory that belonged to someone's jurisdiction. The fact is that church boundaries, according to canon law, which was form in the next Council period, must be correlate with the state. Thus, with the change of state borders, the church's "canonical territory" must also shift. This became especially relevant in the twentieth century, when new national churches were form and new state borders were established [10].

Therefore, self-proclamation cannot be an objective criterion for the formation of an autocephalous church. It is necessary to agree on several parties, in particular the Mother Church. Thus, in the early Christian period, the theory of self-proclamation of autocephaly could not be approve, because there was no generally accepted mechanism for governing the Ecumenical 
Church. Officially, the patriarchal departments consolidated their status after the Fourth Ecumenical Council.

Summing up, we note that the autocephalous theme has always been sharply perceive by the world theological community. The peaks of the discussion of this problem always coincided with the proclamation of a new autocephalous church, especially after the "parade of autocephaly" in the Balkans. Scholars, theologians and hierarchs have once again drawn attention to the problem of autocephaly of the new Local Church in connection with the signing of the Tomos for the Ukrainian Church, which now occupies the 15th place in the diptych. However, a number of unresolved issues remain. One of the main ones is the lack of a clear mechanism for granting autocephalous status to a particular church. The reason for this is the formation of two ecclesiological traditions. Greek, who believes that there is a certain "point of contact" of all churches (Constantinople Cathedral), which has certain privileges of honor, arbitration powers of the Supreme Court and the prerogative of granting autocephaly. Moreover, Slavic, which focuses on the ROC. According to this tradition, there is no "gathering point" of the Local Churches, each of which is completely independent and full-fledged. In addition, the autocephalous status is grant not by the Ecumenical Patriarchate, but directly by the Mother Church for the subordinate metropolitanate.

Next, it is necessary to compare the structure of church-administrative management of the church of the pre-Nicene period and the modern structure of the Ecumenical Church. The ideals of the early Christian period should be preserve to this day, because Orthodoxy positions itself as a conservative religion. However, research has shown that in the first centuries, the autocephalous status of communities and entire churches founded by the apostles and their disciples was self-evident. The autocephalous principle of the church-administrative system was a certain fact of the church arrangement. Already with the spread of Christianity and its introduction into the rank of state religion, autocephaly is transform from a basic institution into a privileged state. Five ancient patriarchates are forming, from which the departments of Old and New Rome clearly stand out.

Thus, the study of the church-administrative system of the early Christian period shows that the basic church institutions, principles, and mechanisms of functioning of the whole church structure have laid at this time. Therefore, the study of this period and the example of resolving the church contradictions of that time is an important historical precedent for the pacification of modern church life on the example of apostolic catholicity.

\section{References}

1. Говорун C. Теоретичні засади православної еклезіології у іï історичному розвитку : дис. на здобуття наук. ступеня доктора філософських наук. Спеціальність 09.00.14 «Богослов'я». Київ, 2019. 623 с.

2. Шишков А. Церковная автокефалия через призму теории суверенитета Карла Шмитта. ГОСУДАРСТВО - РЕЛИГИЯ - ЦЕРКОВЬ. 2014. № 3. С. 197-224.

3. СЛУЖІННЯ СОПРИЧАСТЮ: переосмислення зв'язку між першістю і соборністю. / Заг. ред. архімандрита Кирила (Говоруна). Київ : ДУХ І ЛІТЕРА, 2020. 220 с.

4. Позиция Московского Патриархата по вопросу о первенстве во Вселенской Церкви. Журнал № 157 Священного Синода РПЦ от 25-26 декабря 2013 г. URL: http://www.patriarchia.ru/db/text/3481089.html.

5. Кобетяк А. Сдність та Соборноправність Православної церкви в контексті формування загального диптиху. Практична філософія. № 2. Київ : ПАРАПАН, 2019. С. 17-24.

6. Болотов В. Лекции по истории древней церкви (в 4-х т.). Т. І: Введение в церковную историю. Санкт-Петербург : типография М. Меркушева, 1907. 252 с. 
7. Смирнов Е. История Христианской Церкви. Изд. 2-е, исправленное. Свято-Троицкая Сергиева Лавра, 2007. 768 с.

8. Киприан (Карфагенский), епископ. О единстве Церкви. Библиотека творений св. отцов и учителей Церкви западных, издаваемая при Киевской Духовной Академии. Ч. 1. Киев : типография Г.Т. Корчак-Новицкого, 1879. С. 170-193.

9. Книга правил Святых Апостол, Святых Соборов Вселенских и Поместных и Святых Отец. Москва : изд-во святителя Льва, Папы Римского, 2010. 447 с.

10. Горевой Д. Абхазия раздора: церковный конфликт между двумя патриархатами вышел на новый уровень. 22 ноября 2019. URL: https://risu.org.ua/ru/index/monitoring/society_ digest/77905.

\title{
АВТОКЕФАЛЬНИЙ ПРИНЦИП ЦЕРКОВНО-АДМІНІСТРАТИВНОГО УСТРОЮ ПЕРІОДУ РАННЬОГО ХРИСТИЯНСТВА
}

\author{
Андрій Кобетяк \\ Житомирський держсавний університет імені Івана Франка, \\ кафедра філософії та політологіi \\ вул. Велика Бердичівська, 40, 10008, м. Житомир, Україна
}

Розглянуто основні принципи та механізми функціонування церковно-адміністративної системи управління у ранньохристиянський період. Проаналізовано «ідеальний» період поширення християнської віри та становлення перших общин і доведено, що сучасна система Вселенської церкви має значні відмінності. У статті розкрито формування двох еклезіологічних традицій (грецької та слов'янської), які свідчать про відсутність Єдності та Соборності. Творення протилежних підходів до осмислення структури Вселенського православ'я стало причиною скликання Всеправославного собору у $2016 \mathrm{p}$.

Доведено, що апостоли та їх найближчі учні не знали і не передбачали іншого принципу існування Вселенської церкви, крім автокефалії. Кожна із заснованих общин апріорі була незалежною, а апостоли та їх наступники виконували проповідницьку та богослужбову роль. Встановлено, що автокефалія та соборність позиціонуються як базові категорії церковної інституалізації і найдавніший інститут Церкви. Розглянуто формування різних підходів до явища автокефалії в історії православ'я. У донікейський період автокефалія трансформується у привілейований стан, яким були наділені п’ять древніх патріархатів, що засвідчено канонами і правилами Вселенських соборів. Важливо, що на Соборах не було напрацьовано механізму подальшого надання автокефального статусу новоутвореним церквам. Теорія «пентархії» не передбачала можливості автокефалізації нових церков.

Приклад вирішення церковних суперечок та боротьби з першими опозиційними релігійними рухами у ранньохристиянський період необхідно використати сучасним ієрархам. Нині Вселенська церква перебуває на межі великої схизми. Кілька помісних церков розірвали Євхаристичне спілкування, яке символізує загальну єдність. Ідеали раннього християнства втрачено. Тому подальші детальні дослідження донікейського періоду та інституалізація автокефального церковного устрою ранньохристиянської доби слугуватимуть налагодженню толерантного діалогу між ієрархами Помісних церков у XXI ст.

Ключові слова: християнство, собор, православна церква, Томос, диптих, Вселенський патріарх, автокефалія, канон. 